\title{
Negative Home Equity and Job Mobility
}

\author{
Andrea Morescalchi, Sander van Veldhuizen, Bart Voogt, and Benedikt Vogt
}

\section{Introduction}

During the recent global financial crisis (2007-2009), the large decline in house prices led many homeowners into negative home equity (NHE). NHE occurs when the value of the house is lower than the outstanding debt on it. It has been suggested that the large increase in NHE hindered the mobility of workers and had negative consequences on the labour market (Stiglitz 2009; Krugman 2010; Katz 2014). The increase in the proportion of homeowner households with NHE was particularly high in the Netherlands. Indeed, it increased from less than $10 \%$ to more than $20 \%$ in the period 2006-2011. This increase was especially due to homeowners who fell into NHE as a result of the unexpected decline in house prices.

Several empirical studies have tested the impact of NHE on residential mobility, with mixed findings. While some studies find that NHE reduces the probability of moving (Henley 1998; Ferreira et al. 2010; Modestino and Dennett 2013; Andersson and Mayock 2014), some others find the opposite (Donovan and Schnure 2011; Schulhofer-Wohl 2011; Coulson and Grieco 2013; Bricker and Bucks 2016).

\footnotetext{
A. Morescalchi

IMT School for Advanced Studies Lucca, Lucca, Italy

European Commission Joint Research Centre (JRC), Ispra, VA, Italy e-mail: andrea.morescalchi@imtlucca.it

S. van Veldhuizen · B. Vogt $(\bowtie)$

Netherlands Bureau for Economic Policy Analysis, The Hague, Netherlands e-mail: s.van.veldhuizen@cpb.nl; b.vogt@cpb.nl

B. Voogt

Authority for Consumer and Markets, The Hague, The Netherlands e-mail: Bart.Voogt@acm.nl 
However, whether or not homeowners with NHE, also called 'underwater' homeowners, are more or less mobile, only limited attention has been devoted to investigating the effect of NHE on the labour market. To our knowledge, only Mumford and Schultz (2014) have investigated the relationship between NHE and job transitions using survey data from the Panel Study of Income Dynamics (PSID). The present chapter makes use of Dutch administrative data to estimate the effect of NHE on job-to-job transitions. This is the first study investigating the impact of NHE on the labour market based on administrative data. Panel fixed-effects estimation is carried out by making use of a panel data on Dutch homeowners from the period 2006-2011.

To account for self-selection into NHE based on unobserved characteristics, the authors consider homeowners who fall into NHE because of an exogenous price decline and compare them with homeowners with positive home equity (PHE).

The impact of NHE on job mobility is expected to work via the effect on residential mobility. Although existing evidence on the effect of NHE on residential mobility is mixed, a negative effect has been found in the Dutch case (van Veldhuizen et al. 2016). Reduced propensity to relocate should render homeowners with NHE less likely to change jobs because they are more prone to discard job opportunities requiring relocation. A reduction in the probability of changing jobs may prolong inefficient job matches and deprive homeowners of interesting job opportunities that could have improved the quality of their job match (Munch et al. 2006, 2008).

The study is structured as follows: Section 2 describes the place of the study in the literature; Sect. 3 describes the dataset; Sect. 4 describes the methodological approach; Sect. 5 presents the results, including a robustness analysis; Sect. 6 provides the conclusions; and Sect. 7 reflects on policy lessons learned from this study.

\section{Literature Review and Theoretical Background}

The present study is related to two strands of literature. The first deals with the impact of NHE on residential mobility. The second deals with the impact of homeownership on labour market outcomes.

In the first strand of literature, there exist theories that describe either a negative or a positive impact of NHE on residential mobility. On the one hand, three reasons have been put forward to explain the well-known 'lock-in effect', predicting a negative effect of NHE on residential mobility. First, underwater homeowners may be less mobile because of liquidity constraints on making a down payment on a new home (Stein 1995). Second, nominal loss aversion may make underwater mortgagers less willing to sell their home after its price has fallen (Genesove and Mayer 2001; Engelhardt 2003; Cunningham and Engelhardt 2008). Third, Chan (2001) notes that the lock-in effect can be present only in the case of localised price declines. On the other hand, NHE could provide an incentive to default and hence could even increase mobility (Coulson and Grieco 2013). 
Several empirical studies have tested the impact of NHE on residential mobility, with mixed findings reflecting the ambiguity of theoretical predictions. While some studies find that NHE reduces the probability of moving (Henley 1998; Ferreira et al. 2010; Modestino and Dennett 2013; Andersson and Mayock 2014), some others find the opposite (Donovan and Schnure 2011; Schulhofer-Wohl 2011; Coulson and Grieco 2013; Bricker and Bucks 2016). Ambiguity in results can be related to the fact that these studies investigate different countries, which differ in their institutional settings.

A problem with the available evidence is the potential selection of less mobile individuals into high debt levels. To the authors' knowledge, there is only one study that tries to tackle the issue of self-selection: van Veldhuizen et al. (2016) exploit exogenous switches from PHE to NHE resulting from unexpected decreases in house prices. They find that households falling into NHE are $18 \%$ less likely to move. This chapter tackles self-selection in a similar way.

In the second strand of literature, since the 1980s many scholars have maintained that homeownership should impair the functioning of the labour market. ${ }^{1}$ This claim is based, to a large extent, on the argument that higher costs for selling and buying houses render homeowners less mobile, which has become popular under the label 'Oswald's thesis' (Oswald 1996, 1997, 1999; Blanchflower and Oswald 2013). Reduced residential mobility makes homeowners less prone to relocate for jobs, and hence they are expected to have higher reservation wages, lower search intensity and lower job-finding rates for non-local jobs but opposite outcomes for local jobs (Munch et al. 2008; Morescalchi 2016).

Empirical evidence consistently reports that homeowners are less prone to relocate for jobs (Henley 1998; Munch et al. 2006; Battu et al. 2008; van Vuuren 2009). Most microeconometric studies have found that unemployment periods of homeowners are not longer, or even shorter, than those of renters (Goss and Phillips 1997; Coulson and Grieco 2013; Flatau et al. 2003; Munch et al. 2006, 2008; Battu et al. 2008; van Vuuren 2009; Morescalchi 2016). This evidence has led to the wellknown puzzle of homeowners experiencing shorter unemployment periods despite being less prone to making job-related moves (Morescalchi 2016).

Fewer microeconometric studies have investigated the impact of homeownership on transitions from employment. Evidence shows that homeownership reduces unemployment risks (van Leuvensteijn and Koning 2004; de Graaff et al. 2009; de Graaff and van Leuvensteijn 2013) as well as the likelihood of job-to-job transitions for employees. To check if lower job-to-job transitions of homeowners are explained by lower regional mobility, Battu et al. (2008) and Munch et al. (2008) break down job-to-job transitions into transitions to local jobs and transitions to jobs associated with regional relocation. They both find that homeownership reduces the likelihood of transition to non-local jobs. They also find a negative effect on transitions to local

\footnotetext{
${ }^{1}$ See Havet and Penot (2010) for a survey of earlier studies on the effect of homeownership on the labour market.
} 
jobs, but this effect is smaller in both studies and not significant in the study by Battu et al. (2008).

To reconcile the argument underlying Oswald's thesis and empirical evidence, some microeconometric studies have made distinctions between outright owners and mortgagers. ${ }^{2}$ Unemployed mortgagers should have greater incentives to search for a job to prevent foreclosure (Rouwendal and Nijkamp 2010). Consistently with this argument, unemployed mortgagers are found to have the shortest unemployment duration (Goss and Phillips 1997; Flatau et al. 2003; Brunet et al. 2007; Kantor et al. 2012) as well as the highest search intensity (Morescalchi 2016).

The two strands of literature described so far have limitations. First, investigation of the impact of NHE on residential mobility does not explicitly quantify the consequences for the labour market. Second, existing studies on the effect of housing tenure on labour market outcomes do not explicitly take into consideration the role of NHE. The present study fills these gaps by investigating the impact of NHE on the labour market. The authors are aware of only one study investigating the relationship between NHE and the labour market: Mumford and Schultz (2014) investigate the effect of NHE on the probability of becoming unemployed and on the probability of changing job using survey data from the PSID. They did not find a significant effect in either case. The present study makes use of administrative data and is based on a much larger sample, which contains more than 400,000 unique observations compared with fewer than 8000 .

The impact of NHE on job mobility is expected to occur via its effect on residential mobility. Although existing evidence of the effect of NHE on residential mobility is mixed, a negative effect has been found in the Dutch case (van Veldhuizen et al. 2016). Analysis here is therefore based on the assumption that a negative relationship prevails in the Dutch case. Thus, reduced propensity to relocate can make homeowners with NHE less likely to change jobs, as they are more prone to discard job opportunities requiring relocation. The reduction in the probability of changing jobs may prolong inefficient job matches and deprive homeowners of interesting job opportunities that could improve the quality of their job match (Munch et al. 2006, 2008).

\section{Dataset and Descriptive Statistics}

The analysis in this chapter is based on data from 438,057 individuals followed during the period 2006-2011. This section describes the most important features of the data. The dataset is based on the full population of homeowners in the Netherlands who bought a house after 1995. This section will give an overview of the construction of the dataset and the most important descriptive statistics.

\footnotetext{
${ }^{2}$ Some studies have also compared social renters to private renters (McCormick 1983; Hughes and McCormick 1987; de Graaff et al. 2009; Flatau et al. 2003; Battu et al. 2008; Morescalchi 2016).
} 


\subsection{Constructing the Dataset}

The dataset used for the analysis was constructed from multiple independent administrative data records, which can be obtained from Statistics Netherlands (Centraal Bureau voor de Statistiek (CBS)). CBS provides access to administrative datasets with information collected from various sources, such as registry records from municipalities or information on individual income based on tax files. The data are strictly confidential and may be used only for research purposes. The results may be published only after rigorous verification, which guarantees individual anonymity. The different datasets can be merged using an encrypted individual identifier, based on the individual social security number. This makes it possible to combine several sources of information on the same individual over time. ${ }^{3}$

In total, 17 independent administrative datasets were merged. These sets contain information on the individual's current job, address, house value and household balance-sheet information, such as income, financial assets and the value of the mortgage on the house. Information was also obtained on household composition, including number of individuals living in the household and changes in household composition, such as through marriage, divorce or registered partnership. Table 1 gives an overview of the most important datasets used in the analysis. The datasets are presented in the order used during the merging and cleaning process.

For the statistical analysis, a panel of male heads of households during 20062011 was used. To avoid attrition bias, all individuals who were continuously employed in all years were considered. An individual is defined as being employed in a certain year if they work for at least 10 months of the year. Robustness checks with four different employment periods are also reported.

\subsection{Dependent Variable}

Unique job identifiers from CBS were used at the individual level to identify job-tojob mobility. ${ }^{4}$ An indicator variable was constructed that takes the value 1 if a job identifier changes in a given year with respect to the previous year. The job identifier was corrected for the following confounding factors: merging of companies, change of job within a company and renewal of (temporary) contracts at the same company.

\footnotetext{
${ }^{3}$ For a very detailed description of the construction of the dataset, see van Veldhuizen et al. (2016). This study uses their dataset and merges two additional datasets that contain labour market information for each individual, namely, the BAANKENMERKENBUS and BAANSOMMENTAB datasets.

${ }^{4}$ We used the variable BAANID, which is retrieved from the BAANKENMERKENBUS dataset.
} 


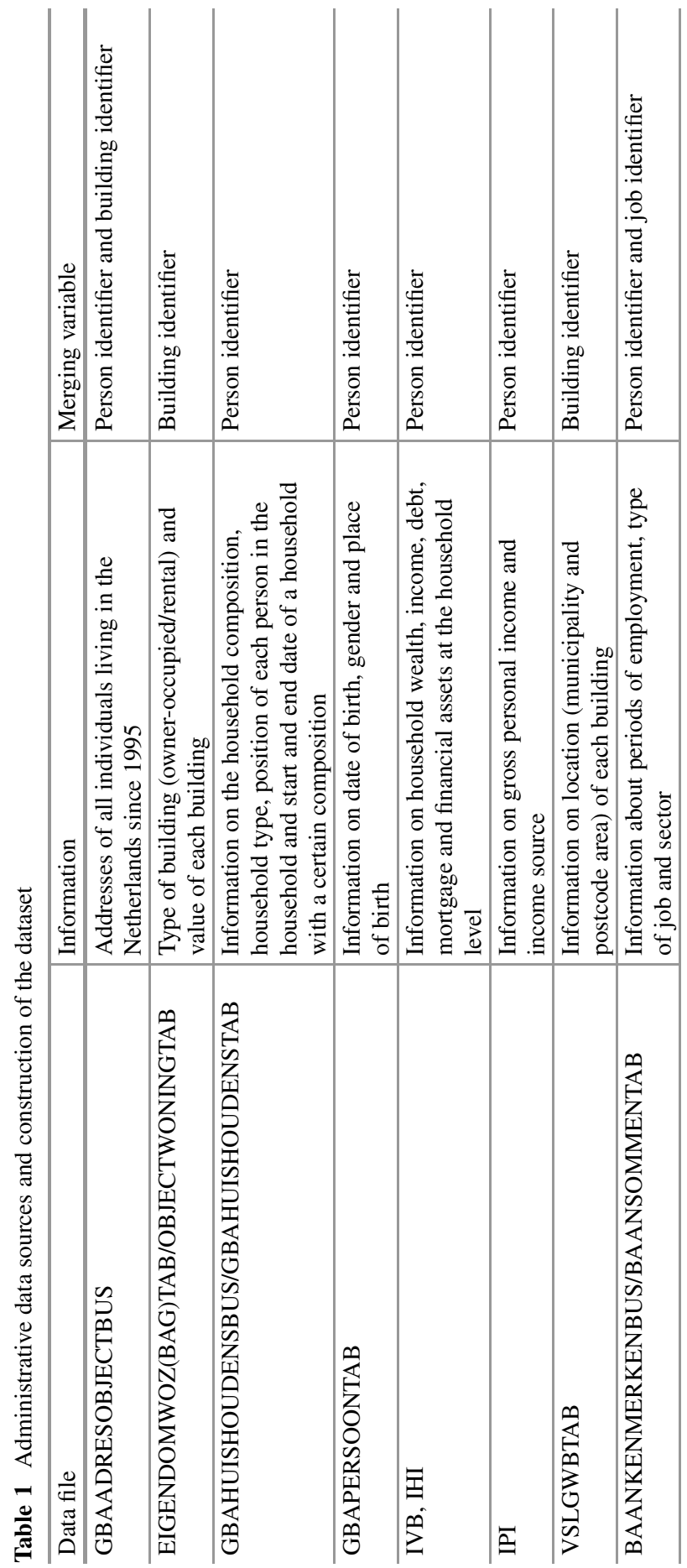




\subsection{Independent Variables}

The dataset contains rich information on the balance sheet of the households. Information was obtained on the outstanding mortgage and the current value of the house on 1 January in each year. The outstanding value of the mortgage was extracted from administrative tax records. The value of the property was obtained using the official valuation of property (waardering onroerende zaken (WOZ) value), which is estimated by the municipality. Each household in the Netherlands receives a letter every year with information on the current value of the property. This is an approximation for the actual market value of the house. The ratio of the transaction price and the WOZ value in the sample period was $99 \%$ (CBS 2014). ${ }^{5}$

The mortgage loan and the value of the house were used to calculate loan-tovalue ratio (LTV). Individuals were defined as having NHE if the LTV exceeded 100. To capture the effect of NHE, outcomes were compared between underwater mortgagers and mortgagers with LTVs of less than 100. However, the division between the two states may depend on unobserved heterogeneity. Therefore, two types of underwater mortgagers were defined. More specifically, the authors distinguished between voluntarily and involuntarily underwater households. Individuals can opt into a high LTV by getting a very large mortgage. An increase in debt may reflect unwillingness to move in the foreseeable future. In this case, the straight comparison between underwater mortgagers and those with PHE may simply capture a different propensity for mobility rather than an impact of NHE.

Individuals were defined as having involuntary NHE if they experienced a decline in their house value that was sufficiently large to increase the LTV to above 100. In cases where an individual's mortgage went underwater because of a combination of an increase in the mortgage and a reduction in the house price, they were considered to have voluntary NHE only if the ratio between the current mortgage and the value of the year before was also above 100. For individuals who were underwater in the first year of the sample, this distinction cannot be used. However, if they bought a house in the first year and the LTV exceeded the cutoff, they were allocated to the category of those with voluntary NHE. Once an individual was categorised as underwater, they were defined as being underwater in the same category as long as the LTV remained above 100. If the LTV fluctuated above or below 100, the underwater status was updated in accordance with these rules.

\footnotetext{
${ }^{5}$ This information was obtained from CBS (2014), p. 8, Table 2.3.2.2. This is the average ratio of the yearly average transaction price and the yearly average WOZ value in the sample period from 2006 to 2011. To calculate this ratio, the reference date in $t+1$ was used as the value is determined on 1 January each year. Hence the corresponding ratio for the year 2006 is the reference date in 2007.
} 
To capture the effect of NHE, the relevant comparison was made between mortgagers who were involuntarily underwater and those with PHE. To distinguish between voluntarily and involuntarily underwater mortgagers, two binary indicators were included in the regressions.

The data also contain a large set of control variables. In particular, use was made of housing tenure in years, household size, disposable real household income, real financial assets, household composition and changes in household composition, year and 40 regional indicators (local labour market level, CÖ̈rdinatie Commissie Regionaal OnderzoeksProgramma (COROP) regions) as control variables.

\subsection{Descriptive Statistics}

Table 2 shows descriptive statistics for each year. The table shows means of the variables and the corresponding standard errors in parentheses below. There are two important messages from the descriptive statistics. First, there is a general decline in job mobility in the sample period. In 2006 about $8.18 \%$ of the individuals in the sample changed job, whereas only $4.39 \%$ in 2011. Second, a striking "exogenous" increase in home equity status was observed. In 2006 , only $0.24 \%$ of the households had involuntary NHE. This number increased to $9.7 \%$ in 2011 . In the same period, the number of households with voluntary NHE increased only slightly $(8.6 \%$ in 2006 compared with $10.93 \%$ in 2011).

\section{Methodology}

In estimating the impact of NHE, the authors took into consideration the fact that the NHE status can be related to unobserved characteristics that in turn may have an impact on the outcome variable. This issue was tackled using three measures.

First, a panel fixed-effects method was employed to remove the potential endogeneity bias arising from time-constant unobserved heterogeneity. Second, a set of control variables was introduced to account for time-varying heterogeneity. Third, the group of homeowners with NHE was divided into the following two groups: mortgagers who fell into NHE (1) because of a house price decline and (2) because of a voluntary increase in the mortgage loan. To capture the impact of NHE, group (1) was compared with homeowners with PHE. In this way the assignment to one of the two categories was determined exogenously. 


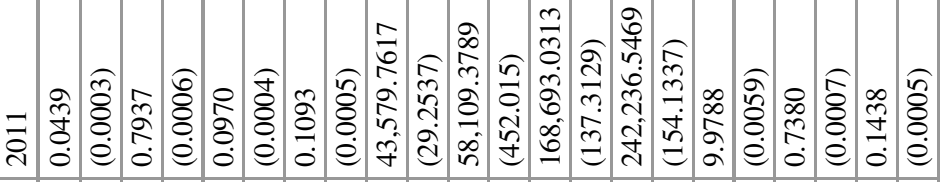

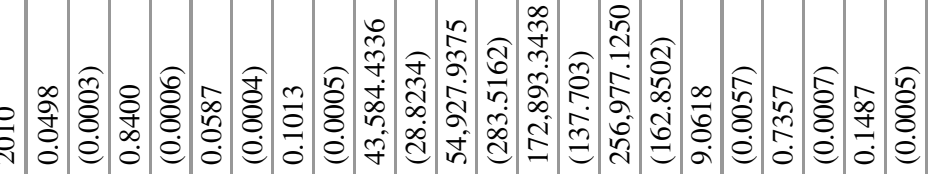

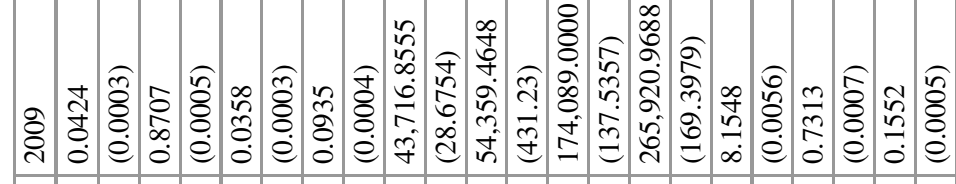

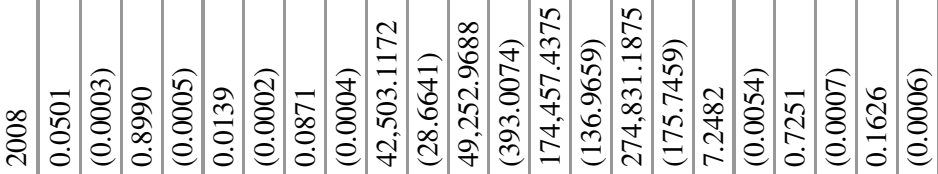

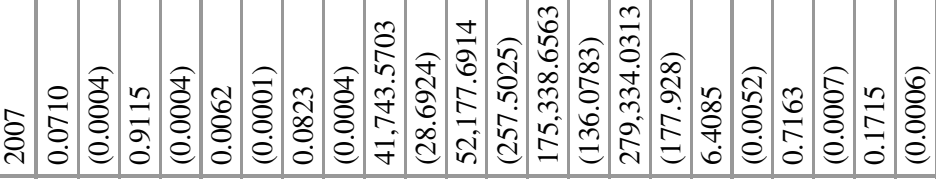

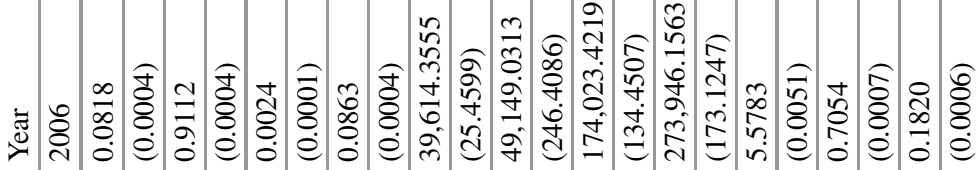

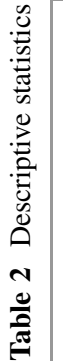

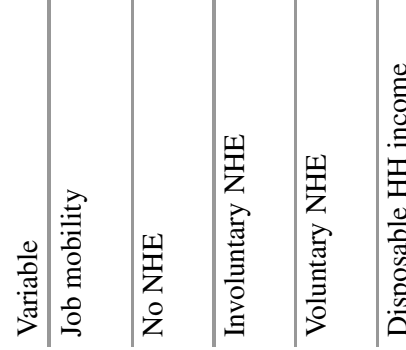

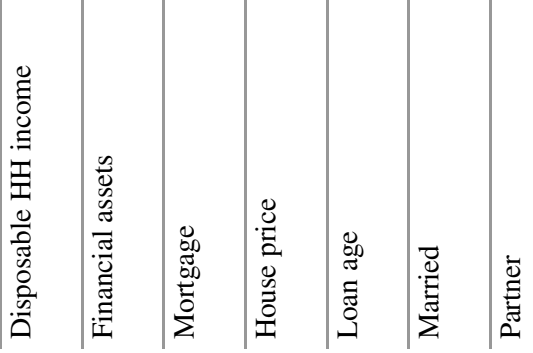




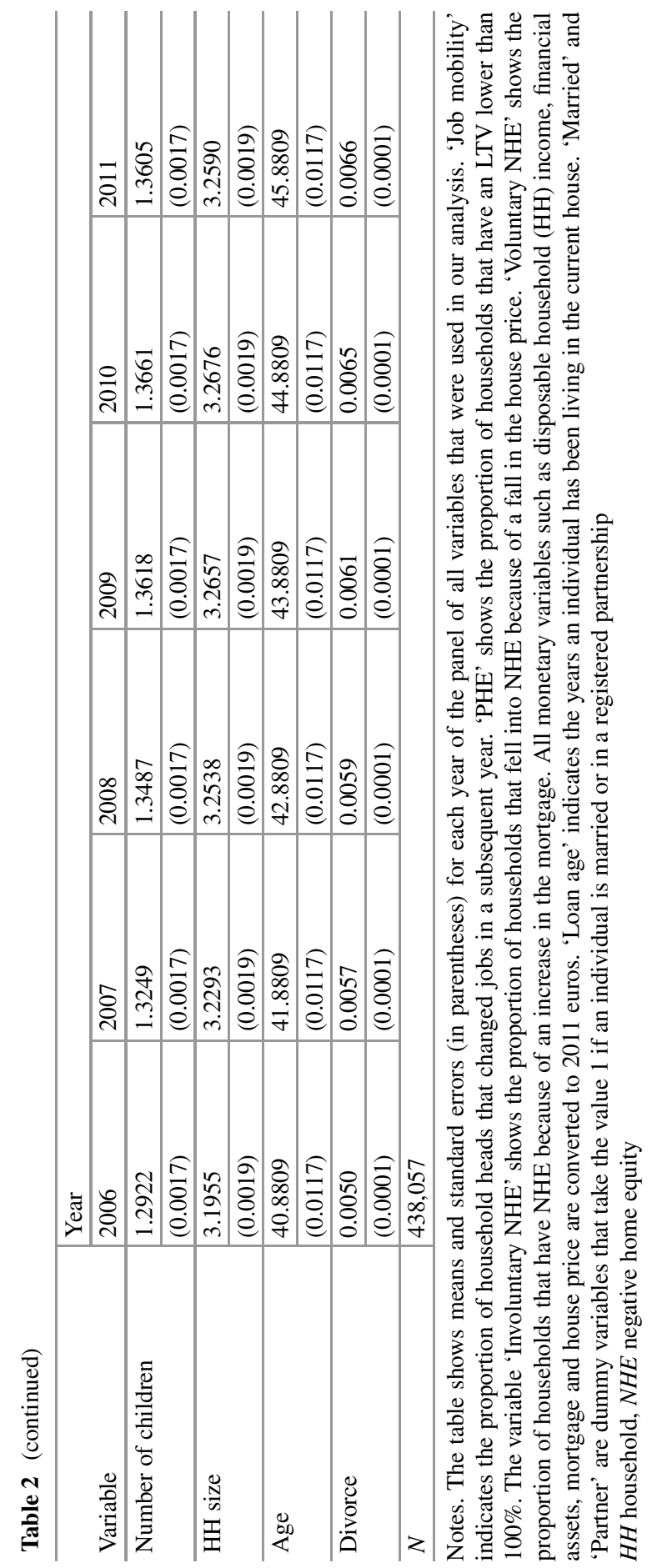




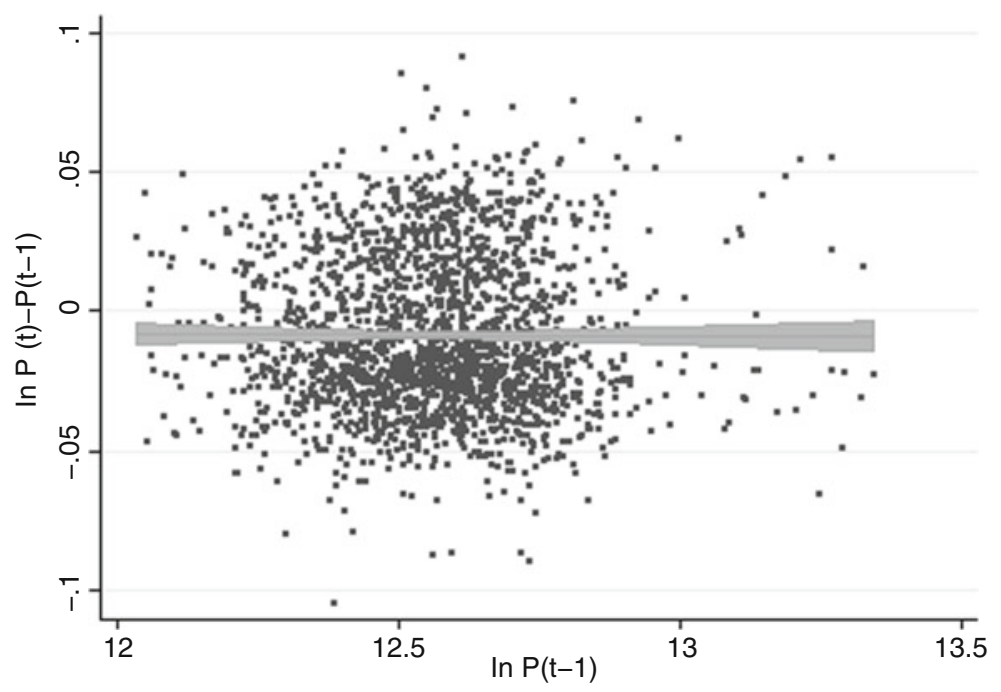

Fig. 1 No relationship between change and level of average house prices in municipalities. Notes. The grey line shows a linear regression with $95 \%$ confidence intervals

One crucial assumption of the identification was that the change in house prices was random and unexpected. Figure 1 shows the relationship between the growth rate and the level of the average house price per municipality in a given year for the period 2006-2011. The picture that emerges from this figure is that there is no relationship between the two variables. Coefficients of year-by-year regressions are also very close to zero and generally non-significant. This evidence suggests that house prices follow a random walk process, providing support to the assumption made here.

Using the sample of all employed homeowners in year $t$, job-to-job transitions can be modelled by the outcome variable $y_{t+1}$, indicating a change of job in the following year. Hence, the following linear probability model is estimated as:

$$
y_{i t+1}=\alpha_{i}+\beta 1\left(\text { InvoluntaryNHE }_{i t}\right)+\delta 1\left(\text { VoluntaryNHE }_{i t}\right)+\gamma X_{i t}+\epsilon_{i t}
$$

In Eq. (1), $\beta$ is the main coefficient of interest. $\alpha_{i}$ is an individual fixed effect, which captures all time-invariant unobserved individual heterogeneity. The parameter vector $\gamma$ captures the effects of other observable time-varying characteristics that are summarised in the matrix $X_{i t}\left(X_{i t}\right.$ contains also a constant). It contains housing tenure, disposable household income and household financial assets. Indicator variables were also included for partnership status, marriage status and divorce status, as well as indicator variables for household size. In addition, year dummies, region dummies and region dummies interacted with year dummies were included to control for potential local labour market shocks, which can vary over time. $\epsilon_{i t}$ is an error term with the usual assumptions. 


\section{Results}

\subsection{Negative Home Equity and Job-to-Job Mobility}

The effect of NHE on job-to-job mobility was analysed. Estimates of parameters in Eq. (1) are reported in Table 3. Coefficients in Table 3 have to be interpreted in terms of percentage point changes of the probability of changing jobs in the subsequent year.

Column 1 reports the results of the baseline specification. This specification contains year dummies and dummies for housing tenure. The main variable of interest is the home equity status of the household. This is a categorical variable reflecting three states defined as follows. The first is mortgagers who are underwater because of a decline in the house price. They are considered to be involuntarily underwater. The effect of NHE is captured by the coefficient of this indicator. The second category corresponds to mortgagers who are underwater because they deliberately chose a high LTV either at the very outset of purchasing their home or as a result of an increase in the mortgage. They are considered to be voluntarily underwater. The third and baseline category describes the situation in which a household has PHE.

Column 1 shows that NHE reduces the probability of changing jobs in the following year by 0.339 percentage points. The results remain nearly unchanged when we add further control variables. In column 2 the study controls for disposable household income, financial assets and household size. ${ }^{6}$ The estimates of household income show a negative association between higher household incomes and the propensity to change job in the consecutive year. Higher financial assets show a modest but mostly significant negative association with job mobility.

The results do not change if further controls are added for the change in household composition in column 3. Namely, three indicator variables are added that capture the household composition and changes to the household composition. A dummy variable is included that takes the value 1 if a household head is living in a registered partnership or marriage. The other two indicator variables take the value 1 if a household head is divorced in year $t$ or is going to divorce in the following year.

The results also remain unchanged if the study controls for local labour market conditions. Since job mobility patterns can differ between labour markets, control variables are added for local labour market conditions. The Netherland is divided into 40 local labour markets, named COROP regions. Region dummies as well as their interactions with year dummies are added in columns 4-6 to control for differences in labour markets and yearly local shocks, respectively. The same sequence of regressions is in columns $1-3$, so, for example, column 4 contains the same control variables as column 1. All regressions reveal point estimates that are very similar to the initial specification in column 1. Column 6 shows that plunging into NHE is associated with a 0.295 percentage point decrease in the probability of changing jobs. Since the average probability of changing jobs across all years is $5.65 \%$, this boils down to a relative effect of about $5.2 \%\left(\frac{0.00295}{0.0565} \times 100\right)$.

${ }^{6}$ All financial variables are converted to 2011 euros. 


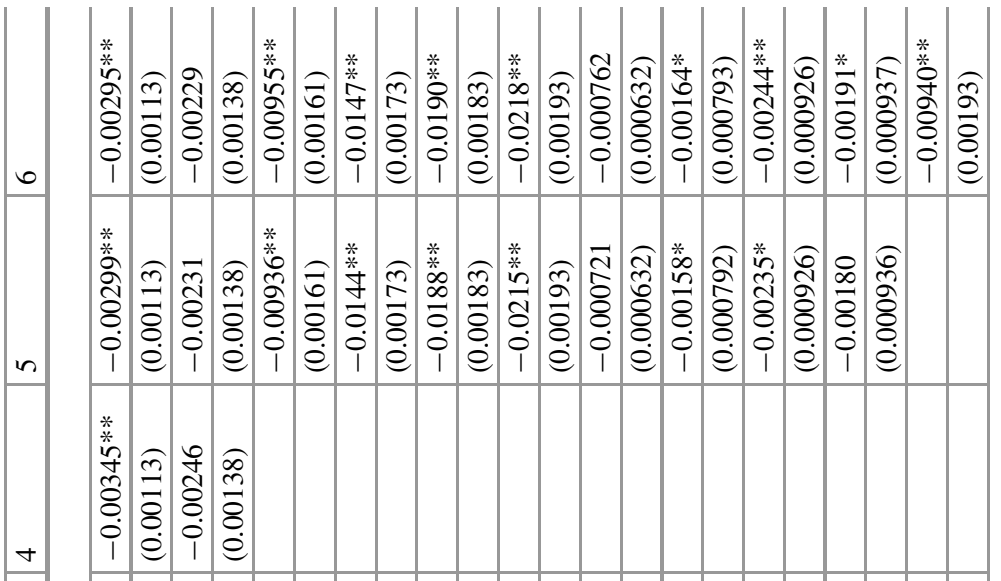

$n$

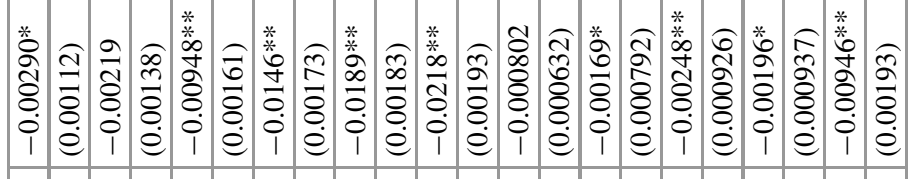

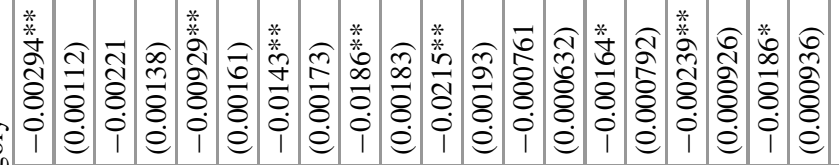


A. Morescalchi et al.

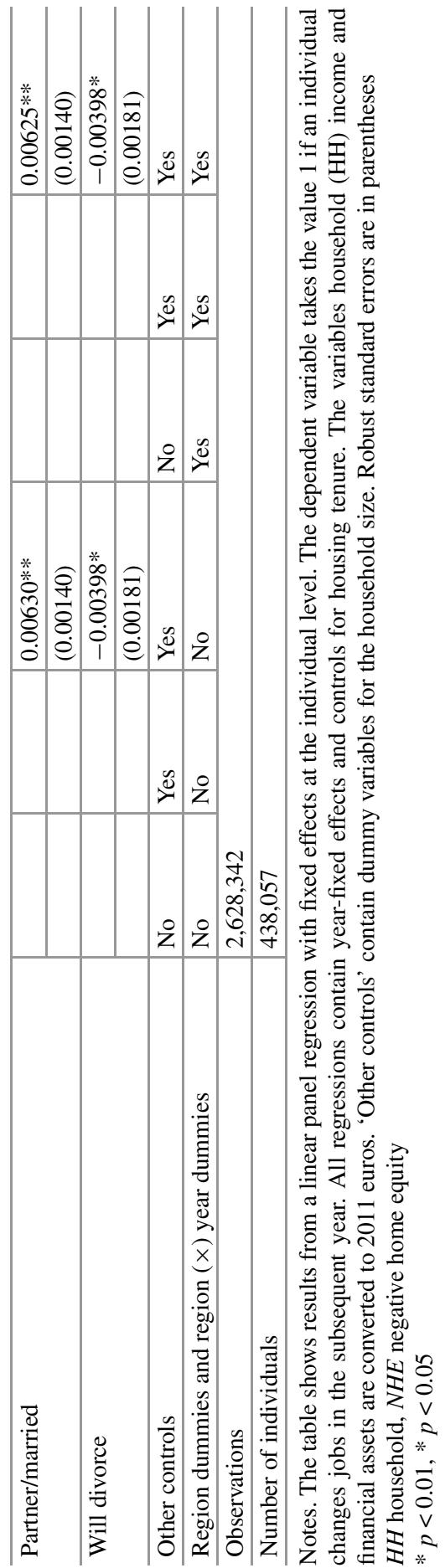




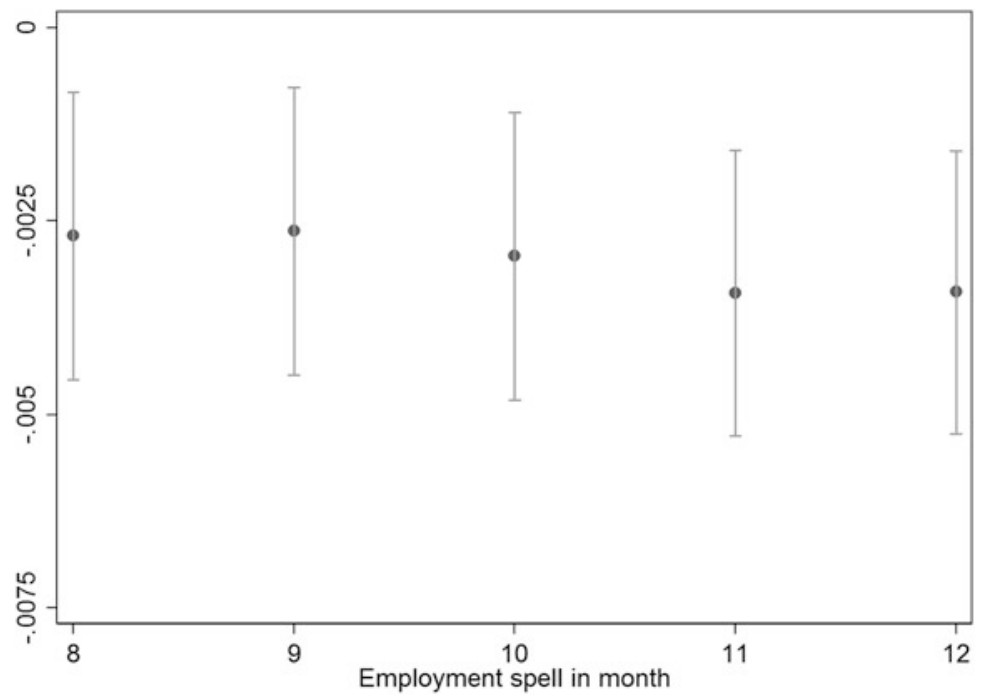

Fig. 2 Effect of involuntary negative home equity on job-to-job mobility for different periods of employment. Notes. The figure shows point estimates with $95 \%$ confidence intervals of linear panel regression, with job-to-job mobility as a dependent variable for different samples. The $x$-axis indicates the minimum employment length per year. The point estimate for an employment length of 10 months is from column 6 in Table 2. The full regression results are available upon request

Table 3 also shows no relation between voluntary NHE and job-to-job mobility. None of the coefficients in columns 1-6 are significantly different from zero. ${ }^{7}$

\subsection{Robustness}

A crucial selection was made with regard to the sample about the length of employment. The main analysis focused on an employment period of at least 10 months in each year. One important question was hence to check if the results changed if longer or shorter employment periods were allowed.

To address this question, the same analysis was conducted with samples based on different employment periods. The authors looked at periods of 8, 9, 11 and 12 months of employment in each year and ran the same analysis as in Table 3.

The analysis reveals that the choice of the length of the employment period does not influence the main results. Figure 2 shows the point estimates with $95 \%$ confidence intervals of the key variable of interest. The $x$-axis shows the length

\footnotetext{
${ }^{7}$ As an alternative estimation, we also run an instrumental variable (IV) regression, pooling the category of voluntary NHE with the reference category of no NHE. The binary indicator for NHE has been instrumented with residuals of a house price equation containing the full set of regressors. The coefficient of the binary indicator is not significant in the second stage, consistent with the fact that voluntary and involuntary NHE are associated with similar effects in Table 3. Results are available from the authors on request.
} 
of employment in each year. Regardless of the choice of employment period, a statistically significant and negative relation is found between plunging into NHE and the propensity to change jobs. The figure also shows that the point estimates for each employment period are not statistically significantly different from each other. NHE is associated with a moderate decrease in job-to-job mobility. ${ }^{8}$

\section{Summary}

This study investigated the effect of NHE status on job-to-job mobility. It used a Dutch administrative panel dataset of homeowners for the period 2006-2011. The analysis reveals a small negative effect of NHE on job-to-job mobility. Households that plunge into NHE involuntary as a result of an unforeseen fall in house prices are $5.2 \%$ less likely to change jobs than households remaining with PHE. No relationship is found between voluntary NHE and job-to-job mobility.

The effect of NHE on job-to-job mobility is relatively small, especially if compared with the effect on household residential mobility. There are three main reasons why the effect might be so small. First, the institutional setup, such as the National Mortgage Insurance Scheme, covers the mortgage payments in case of default due to involuntary unemployment. This mitigates the potential risks of changing jobs as a homeowner.

Second, in the Netherlands, high levels of mortgage debt are not associated with weak borrower characteristics or higher default probabilities (Mocking and Overvest 2015). This is one of the key differences from the United States and some other countries, where high levels of mortgage debt are often associated with weaker borrower characteristics, such as low income, low socio-economic background or low educational levels. When the housing market collapsed, many of these 'subprime' mortgages defaulted because many of the mortgagers became unemployed as a result of their weaker positions in the labour market.

Third, homeowners with NHE might be prone to longer commuting distances. In this case they might take up new opportunities in distant areas almost as often as homeowners with positive equity, but avoiding relocation. The metropolitan region 'Randstad' covers the four biggest cities in the country: Amsterdam, Rotterdam, The Hague and Utrecht. In this region the infrastructure is such that individuals do not have to move when they change jobs. The impact of NHE on commuting is a topic for future research.

\footnotetext{
${ }^{8}$ The full set of regression results of this robustness check is available upon request.
} 


\section{Policy Lessons}

The reduced labour mobility of homeowners plunging into NHE can have adverse effects on the economy through reduced labour market matching efficiency, which can lead to lower productivity levels. Two types of policies can be identified to reduce these adverse effects: policies targeted at homeowners facing negative equity and policies targeted at the flow of future homeowners with low equity levels.

Policies regarding homeowners facing negative equity could be aimed at reducing barriers to refinancing of residual debt. In general, mortgage lenders typically do not (re)finance high LTVs. In the United States, most mortgage lenders will not finance over $80 \%$ loan-to-home value, whereas in the Netherlands the cutoff is $101 \%$. Policies to refinance underwater mortgages could be government-run programmes that offer high LTV loans, like the Home Affordable Refinance Program (HARP) in the United States, which offers loans with LTVs up to $125 \%$ to cover the home's reduced value. In addition to such government-run programmes, another policy could be to make the interest paid on the refinanced debt tax deductible. This is done in the Netherlands, for example, to incentivise households to accelerate repayments of residual debt. Finally, governments could reduce transaction costs by lowering stamp duty on residential moves that accompany job changes.

Policies aimed at the future flow of homeowners with low equity levels are typically targeted at reducing the incentives to enter into high mortgage debts. This can be achieved by lowering mortgage interest-rate deductions, which are typically found in some advanced economies (such as the United States and the Netherlands). A home mortgage interest deduction allows taxpayers who own their homes to reduce their taxable income by the amount of interest paid on the loan that is secured by their principal residence. An additional regulatory policy could be (the introduction of) stricter mortgage standards, such as limits on loan-to-value or loan-to-income ratios. These macroprudential tools are frequently considered to dampen credit growth and avoid boom and bust cycles on housing markets. However, the institutional setting should be taken into consideration when planning restrictions in the availability of credit. In the Netherlands, for example, households face relatively large mandatory pension savings that restrict any additional savings for most households, which could lead to reduced access to the housing market (van Veldhuizen et al. 2015).

Acknowledgements The authors would like to thank Michiel Bijlsma, Jonneke Bolhaar, Sander Gerritsen and Remco Mocking for helpful comments. The codes used to construct the dataset and to conduct the analysis are available upon request. The data used for analysis are strictly confidential and available only for personally registered users of Statistics Netherlands (CBS-remote access). The authors will provide all necessary assistance to gain access to the data. All remaining errors are their own. 


\section{References}

Andersson F, Mayock M (2014) How does home equity affect mobility? J Urban Econ 84:23-39

Battu H, Ma A, Phimister E (2008) Housing tenure, job mobility and unemployment in the UK. Econ J 118(527):311-328

Blanchflower DG, Oswald AJ (2013) Does high home-ownership impair the labor market? NBER Working Paper No 19079. National Bureau of Economic Research, Cambridge

Bricker J, Bucks B (2016) Negative home equity, economic insecurity, and household mobility over the Great Recession. J Urban Econ 91:1-12

Brunet C, Clark AE, Lesueur J-Y (2007) Statut résidentiel et durée de chômage en France et au Royaume-Uni. Rev Fr Econ 22(2):165-190

CBS (Statistics Netherlands) (2014) Prijsindex Bestaande Koopwoningen: methodebeschrijving. CBS, The Hague

Chan S (2001) Spatial lock-in: do falling house prices constrain residential mobility? J Urban Econ 49(3):567-586

Coulson NE, Grieco PLE (2013) Mobility and mortgages: evidence from the PSID. Reg Sci Urban Econ 43(1): 1-7

Cunningham CR, Engelhardt GV (2008) Housing capital-gains taxation and homeowner mobility: evidence from the Taxpayer Relief Act of 1997. J Urban Econ 63(3):803-815

de Graaff T, Van Leuvensteijn M (2013) A European cross-country comparison of the impact of homeownership and transaction costs on job tenure. Reg Stud 47(9):1443-1461

de Graaff T, Van Leuvensteijn M, van Ewijk C (2009) Homeownership, social renting and labor mobility across Europe. In: van Ewijk C, Van Leuvensteijn M (eds) Homeownership and the labour market in Europe. Oxford University Press, Oxford, pp 53-81

Donovan C, Schnure C (2011) Locked in the house: do underwater mortgages deduce labor market mobility? https://doi.org/10.2139/ssrn.1856073

Engelhardt GV (2003) Nominal loss aversion, housing equity constraints, and household mobility: evidence from the United States. J Urban Econ 53(1):171-195

Ferreira F, Gyourko J, Tracy J (2010) Housing busts and household mobility. J Urban Econ 68(1):34-45

Flatau P, Forbes M, Hendershott PH (2003) Homeownership and unemployment: the roles of leverage and public housing. NBER Working Paper No 10021. National Bureau of Economic Research, Cambridge

Genesove D, Mayer C (2001) Loss aversion and seller behavior: evidence from the housing market. Q J Econ 116(4):1233-1260

Goss EP, Phillips JM (1997) The impact of home ownership on the duration of unemployment. Rev Reg Stud 27(1):9

Havet N, Penot A (2010) Does homeownership harm labour market performances? A survey. doi:https://doi.org/10.2139/ssrn.1625248

Henley A (1998) Residential mobility, housing equity and the labour market. Econ J 108(447):414 427

Hughes G, McCormick B (1987) Housing markets, unemployment and labour market flexibility in the UK. Eur Econ Rev 31(3):615-641

Kantor Y, Nijkamp P, Rouwendal J (2012) Homeownership, unemployment and commuting distances. doi:https://doi.org/10.2139/ssrn.2327010

Katz L (2014) Long-term unemployment in the Great Recession. Harvard University, Cambridge

Krugman P (2010) Beveridge worries. New York Times, 29 July 2010. http:// krugman.blogs.nytimes.com/2010/07/29/beveridge-worries/?_r=0. Accessed 24 Jul 2017

McCormick B (1983) Housing and unemployment in Great Britain. Oxford Econ Pap 35:283-305

Mocking R, Overvest B (2015) Estimating the impact of forced sales on house prices. CPB Discussion Paper. CPB Netherlands Bureau for Economic Policy Analysis. http:// econpapers.repec.org/paper/cpbdiscus/304.htm. Accessed 24 Jul 2017 
Modestino AS, Dennett J (2013) Are American homeowners locked into their houses? The impact of housing market conditions on state-to-state migration. Reg Sci Urban Econ 43(2):322-337

Morescalchi A (2016) The puzzle of job search and housing tenure: a reconciliation of theory and empirical evidence. J Reg Sci 56(2):288-312

Mumford KJ., Schultz K (2014) The effect of underwater mortgages on unemployment. Columbia University, New York. http://www.krannert.purdue.edu/faculty/kjmumfor/papers/ Underwater_and_Unemployed.pdf. Accessed 24 Jul 2017

Munch JR, Rosholm M, Svarer M (2006) Are homeowners really more unemployed? Econ J 116(514):991-1013

Munch JR, Rosholm M, Svarer M (2008) Home ownership, job duration, and wages. J Urban Econ 63(1): 130-145

Oswald AJ (1996) A conjecture on the explanation for high unemployment in the industrialized nations: part 1. University of Warwick, Coventry

Oswald AJ (1997) Thoughts on NAIRU. J Econ Perspect 11(4):227-228

Oswald AJ (1999) The housing market and Europe's unemployment: a non-technical paper. University of Warwick, Coventry

Rouwendal J, Nijkamp P (2010) Homeownership and labour-market behaviour: interpreting the evidence. Environ Plan A 42(2):419-433

Schulhofer-Wohl S (2011) Negative equity does not reduce homeowners' mobility. NBER Working Paper 16701. National Bureau of Economic Research, Cambridge. http://www.nber.org/papers/ w16701. Accessed 24 Jul 2017

Stein JC (1995) Prices and trading volume in the housing market: a model with down-payment effects. Q J Econ 110(2):379-406

Stiglitz JE (2009) The challenge of creating jobs in the aftermath of the 'Great Recession.' Testimony before the Joint Economic Committee, Washington, DC, 10 Dec 2009

Van Leuvensteijn M, Koning P (2004) The effect of home-ownership on labor mobility in the Netherlands. J Urban Econ 55(3):580-596

van Veldhuizen S, Groot S, van Dijk M (2015) De economische effecten van een verdere verlaging van de LTV-limiet (The economic effects of a further reduction of the LTV limit). CPB Discussion Paper. CPB Netherlands Bureau for Economic Policy Analysis, The Hague

van Veldhuizen S, Vogt B, Voogt B (2016) Negative home equity and household mobility: evidence from administrative data. CPB Discussion Paper No 323. CPB Netherlands Bureau for Economic Policy Analysis, The Hague. https://ideas.repec.org/p/cpb/discus/323.html. Accessed 24 Jul 2017

van Vuuren, A (2009) The impact of homeownership on unemployment in the Netherlands. In: van Ewijk C, van Leuvensteijn M (eds) Homeownership and the labour market in Europe. Oxford University Press, Oxford, pp 113-136

Andrea Morescalchi is a researcher in Economics working for the European Commission Joint Research Centre (Ispra, Italy). He holds a degree and a $\mathrm{PhD}$ in Economics from the University of Pisa. After the PhD he worked as post-doc fellow at IMT Lucca and then moved to the JRC. His main research interests are the interplay between labour, housing and regional economics, impact evaluation, networks of knowledge and innovation.

Sander van Veldhuizen is heading the research programme public finance at the CPB Netherlands Bureau for Economic Policy Analysis, the Dutch public think-tank for economic policy research. He obtained a PhD in Applied Mathematics at Delft University of Technology. In the period 2014-2017, he headed the financial markets research programme at CPB. Before joining the CPB, he worked as a strategist at the Netherlands Authority for Financial Markets (AFM). Sander van Veldhuizen has extensive experience in applied economic research and policy analysis in various field, amongst others financial markets, housing and innovation. 
Bart Voogt is working at Authority for Consumers and Markets (ACM) as senior economist. He is involved in the regulation of the Dutch Telecommunications, Transport and Postal sectors. In 2012 he graduated from the Erasmus University Rotterdam with a PhD in Economics. His main research interests are industrial organisation, the housing market and regulated markets.

Benedikt Vogt is an applied economist with a broad field of interest for policy-relevant questions. Since 2014, he has been working as a researcher at the department of market regulation at the CPB Netherlands Bureau for Economics Policy Analysis. He graduated from the University of Bonn in 2011, and he holds a PhD in Economics of Maastricht University since 2015. His research interests lay in empirical household finance, behavioural economics and experimental economics.

Open Access This chapter is licensed under the terms of the Creative Commons Attribution 4.0 International License (http://creativecommons.org/licenses/by/4.0/), which permits use, sharing, adaptation, distribution and reproduction in any medium or format, as long as you give appropriate credit to the original author(s) and the source, provide a link to the Creative Commons license and indicate if changes were made.

The images or other third party material in this chapter are included in the chapter's Creative Commons license, unless indicated otherwise in a credit line to the material. If material is not included in the chapter's Creative Commons license and your intended use is not permitted by statutory regulation or exceeds the permitted use, you will need to obtain permission directly from the copyright holder. 